\title{
New Digital Technologies Applied to the Management of Geoheritage
}

\author{
Nathalie Cayla $\cdot$ Fabien Hobléa $\cdot$ Emmanuel Reynard
}

Published online: 20 May 2014

(C) The European Association for Conservation of the Geological Heritage 2014

Keywords Geoheritage · Geotourism · Geosite management

During the last decade, the development of new digital technologies has strongly influenced the customs and practice of geoheritage and geotourism research. Digital tools, such as geoinformation, geovisualisation, digital monitoring and GIS systems have played an important role in the development of new methods of assessment and mapping, as well as aiding the development of geosites for tourism and education.

In September 2011, the University of Savoie and University of Lausanne co-organised an intensive course on the use of digital tools for geoheritage management activities (including geosite selection, geoheritage and geodiversity mapping, geotourism promotion and education about geoheritage) within the International Symposium on Geosite Management (ISGM) and under the auspices of the Working Group on Geomorphosites of the International Association of Geomorphologits (IAG) (Reynard and Coratza 2013). The course was held in the Chablais Geopark (Evian, France) and was financially supported by the HINT project (Heritage Interpretation through New Technologies) (Cayla 2012; Barton et al. 2014). This 2-year international project was funded by the European Leader programme and involved four partners: Geopark Shetland (Scotland), Chablais Geopark (France), North Pennines AONB (England) and Geopark de Hondsrug (The Netherlands). This special issue of the journal Geoheritage contains a selection of the papers presented during the symposium (including both on the intensive course and during the conference), as well as some additional papers

\footnotetext{
N. Cayla $(\bowtie) \cdot F$. Hobléa

University of Savoie, Chambéry, France

e-mail: nathalie.cayla@univ-savoie.fr

E. Reynard

University of Lausanne, Lausanne, Switzerland
}

dealing with this topic. The papers included focus on different digital technologies used for the assessment, monitoring and the promotion of geosites.

Nathalie Cayla proposes a review of existing and emerging technologies for the depiction and interpretation of geosites. Three main topics in particular are analysed: Georeferencing and mapping of geoheritage, 3D digital imaging (including photogrammetry and laser scanning) and experiments in the promotion of geoheritage using augmented reality (a process which enriches discovery through digital media, or provides a virtual reality with which one can engage).

The three following papers are case studies using new digital technologies applied to the management of geoheritage in specific geomorphological contexts. Luca Ghiraldi and colleagues present a comprehensive methodology for identifying, cataloguing, assessing, visualizing and promoting geoscientific data relevant to geological heritage, using geomatic tools, such as digital photogrammetry, GIS, GNSS, terrestrial laser scanner and web mapping. The case study was carried out in the Seguret Valley (Oulx, Turin Province) in the Italian Western Alps. This area was selected as it forms a part of the European "Cottian Alps Geopark project" which aims to develop a transboundary area between Italy and France.

Fabien Hoblea and colleagues give an overview of various digital tools (including high-tech digital monitoring and 3Dmodelling technologies combining laser scanners, digital cameras and sensors) developed and used to study and promote a range of karst geosites. The paper focuses on the very high heritage value of endokarst sites (caves or karst networks) in the French Ardèche department (e.g. Chauvet Cave, Aven d'Orgnac), Chartreuse (e.g. Granier cave network), Vercors (e.g. Choranche Caves) and Bauges (e.g. Prérouge Cave) regional parks.

High-alpine geomorphosites are a geoheritage which is extremely vulnerable to global warming. From the beginning of the 2000s, Ludovic Ravanel and colleagues have been 
studying the evolution of nearly 40 high altitude sites across the Alps using terrestrial laser scanning. They present how this high-resolution technology can be used for identifying and characterising geomorphological features (e.g. through survey, monitoring and mapping), hence aiding the development and implementation of planning policies and protection, as well as for developing geotourist products (including raising public awareness about the processes involved). In the next paper, Simon Martin and colleagues discuss opportunities for using web mapping methods and techniques for geoheritage assessment and promotion. The web mapping application, Google Maps API, is proposed as a tool for disseminating geosite inventories established in Switzerland at both national and regional scales.

The two last papers deal with educational issues related to geoheritage. They explore the potential advantages of using visual and interactive media to improve geoscientific assessment and interpretation of geosites. Simon Martin focuses on the use of interactive functions which go beyond the design or cartographic limits of classic visual media, with the help of interactivity, multimedia and animation. He discusses the effects of these numerical technologies on learning, following results in media and cognitive psychology. This work is based on three original web applications, which are 'mashups' of various existing tools such as web mapping interactive vector drawing, animated schemes and pictures, using different levels of interactivity and following a specific educational approach (i.e. exploration, experimentation, explanation).

Christophe Lansigu and colleagues have founded GEOLOGrafis, a small private company that develops graphic communication tools to promote geoheritage projects. They present several examples of projects carried out for different public audiences, using different types of presentation. The paper illustrates the decision-making process involved during production that requires a combination of the following three skills: understanding geological concepts; design skills and a grasp of software animation programs; and mediation skills to measure the right level of transmission of the geological ideas.

\section{References}

Barton R, Cooper D, Guyomard A, Justice S, Samson P, Pickett E, Posthumus C, Jan Lekkerkerker D, Cayla N (2014) The HINT project - exploring the use of new technologies in heritage interpretation. J Earth Sci Eng, in press

Cayla N (2012) Le projet "Hint" (Heritage Interpretation through new technologies), une coopération internationale au service de la valorisation des géopatrimoines. Ann Soc Géol du Nord 19:75-80

Reynard E, Coratza P (2013) Scientific research on geomorphosites. A review of the activities of the IAG working group on geomorphosites over the last twelve years. Geogr Fis Dinam Quat 36:159-168 